\title{
ВДОСКОНАЛЕННЯ УПРАВЛІННЯ ЯКІСТЮ ПРОДУКЦІЇ ВИСОКОТЕХНОЛОГІЧНИХ ПІДПРИЕМСТВ
}

\author{
Науменко М.О., д.філ. екон. напр., професор (НА НГУ)
}

У статті розроблено механізм управління якістю продукиії; обтрунтовано його складові елементи - принципи, методи, функиї, інструменти; визначено напрями управлінського впливу на якість продукції. Досліджено, щзо управління якістю продукиї містить у собі ті аспекти виконання функиій управління, щзо визначають иілі і відповідальність у сфері якості. Обгрунтовано доцільність застосування соціальних методів управління в системі якості.

Ключові слова: механізм, якість продукції, управління, методи, функції, персонал

\section{СОВЕРШЕНСТВОВАНИЯ УПРАВЛЕНИЯ КАЧЕСТВОМ ПРОДУКЦИИ ВЫСОКОТЕХНОЛОГИЧНЫХ ПРЕДПРИЯТИЙ}

\author{
Науменко Н.А., д. фил. экон.напр., профессор (НА НГУ)
}

В статье разработан механизм управления качеством продукиии; обосновань его составляющчие элементы - принципы, методы, функции, инструменты; определены направления управленческого влияния на качество продукиии. Доказано, что управление качеством продукции включает в себя те аспекты выполнения функций управления, определяюшие иели и ответственность в области качества. Обоснована целесообразность применения соичильных методов управления в системе качества.

Ключевые слова: механизм, качество продукции, управление, методы, функции, персонал.

\section{IMPROVING THE QUALITY MANAGEMENT OF THE PRODUCTION OF HIGH-TECH ENTERPRISES}

\author{
Naumenko M.A., Ph.D. economic direction, professor \\ (National Academy of the National Guard of Ukraine)
}

The center of economic policy at the present stage is the task of comprehensive upgrading of the technical level and quality of products, which should implement the latest achievements of scientific thought, to satisfy the highest techno-economic, aesthetic and other requirements of consumers. Improving the quality of domestic products in a market economy is one of the components of the mechanism of accelerating the socio-economic development of society, requires the strengthening of the effectiveness of state standards to its technical level.

The mechanism of product quality management is considered one of the elements of the general economic mechanism of the enterprise. With this in mind, quality policy is an element of overall policy and is endorsed by senior management. It represents the general intentions and direction of the enterprise to the quality, formally formulated by the supreme 
leadership. In other words, quality policy is a guideline for the general direction of the enterprise's activities in quality management of products.

Quality policy is aimed at choosing the areas of work on product quality management, goals and the choice of real means for their achievement, which will allow the production of high quality products. The main focus of quality policy should be to maximize the use of all internal reserves to achieve a high level of product quality, as well as to find solutions that would reduce costs without compromising quality.

The mechanism of product quality management is a set of methods and techniques of influence from the management of the company to its employees in order to effectively direct their actions and use of potential properties to quality work.

Product quality management includes those aspects of management functions that define goals and responsibilities in the field of quality. Therefore, quality management functions are used for quality management, quality assurance, quality control, training and motivation of employees in the field of quality. All these functions are interlinked in the form of loops of quality and collectively represent a process of quality management within the entire enterprise. personnel

Key words: mechanism, quality of production, management, methods, functions,

Постановка проблеми та іï зв'язки 3 науковими чи практичними завданнями. У центр економічної політики на сучасному етапі поставлено завдання всебічного підвищення технічного рівня і якості продукції, яка повинна втілювати останні досягнення наукової думки, задовольняти найвищі техніко-економічні, естетичні та інші вимоги споживачів. Підвищення якості вітчизняної продукції в умовах ринкової економіки $\epsilon$ однією зі складових механізму прискорення соціальноекономічного розвитку суспільства, вимагає посилення дієвості державних стандартів на іiі технічний рівень. Внаслідок вказаного вельми актуального значення набуває проблематика вдосконалення управління якістю продукції високотехнологічних підприємств.

Аналіз останніх досліджень i публікацій та виділення невирішених частин загальної проблеми. $У$ сучасних роботах, пов'язаних 3 проблемою забезпечення якості, висвітлюють різні аспекти процесу вдосконалення управління якістю продукції високотехнологічних підприємств. Так, в роботі [1] висвітлюються загальні засади управління якістю продукції. В дослідженні [2] аналізуються проблеми якості аудиту та оцінювання управлінської діяльності. В роботі [3] запропоновано розгляд особливостей метрології, стандартизації, сертифікації та акредитації продукції та підприємств. Орлов П.А. в дослідженні [4] розглядає особливості менеджменту якості продукції. Разом 3 тим, на сьогодні недостатньо опрацьовані питання вдосконалення управління якістю продукції високотехнологічних підприємств.

Отже метою статті $\epsilon$ вдосконалення механізму управління якістю продукції високотехнологічних підприємств.

Виклад основного матеріалу дослідження. Механізм управління якістю продукції вважається одним 3 елементів загального господарського механізму підприємства. 3 огляду на це політика у сфері якості $€$ елементом загальної політики та схвалюється вищим керівництвом. Вона являє собою загальні наміри та спрямованість підприємства на якість, які офіційно сформульовані найвищим керівництвом. Іншими словами, політика якості $\epsilon$ орієнтиром для загального спрямування діяльності 
високотехнологічного підприємства на управління якістю продукції.

Політика якості спрямована на вибір напрямків роботи 3 управління якістю продукції, цілей та вибору реальних засобів для їх досягнення, які дозволять виготовляти продукцію високої якості. Головним напрямом в політиці якості повинне бути максимальне використання усіх внутрішніх резервів для досягнення високого рівня якості продукції, а також пошук таких рішень, які дозволили б скоротити витрати без зниження якості.

Механізм управління якістю продукції являє собою сукупність методів та прийомів впливу з боку керівництва підприємства на його працівників з метою ефективного спрямування їх дій та використання потенційних властивостей до якісної праці. Запропонований механізм спрямований на забезпечення ефективного процесу управління якістю продукції, що сприяє створенню якісної продукції. Основною кінцевою метою механізму управління якістю продукції визначено забезпечення створення якісної продукції згідно міжнародних стандартів якості. Поставлена мета досягається на основі ефективної взаємодії елементів механізму: методів, принципів, функцій, інструментів управління якістю продукції (рис. 1).

Управління якістю продукції містить у собі ті аспекти виконання функцій управління, що визначають цілі і відповідальність у сфері якості. Тому із функцій управління якістю застосовуються: планування якості, організація робіт з формування якості, контроль якості, навчання та мотивація працівників в області якості. Всі ці функції пов'язані між собою у вигляді петлі якості і у сукупності являють собою процес управління якістю в рамках всього підприємства.

Планування якості $\epsilon$ складовою частиною управління якістю, що зосереджена на встановленні цілей у сфері якості, визначенні операційних процесів, відповідних ресурсів, необхідних для досягнення цілей у сфері якості високотехнологічними підприємствами. Планування якості охоплює також оцінку якості праці виконавців і якості продукції, підготовку системи і програми якості, розробку положень 3 iі поліпшення. Планування якості здійснюється, виходячи 3 аналізу вимог замовників та ринків збуту i спрямовано на їх задоволення.

Організація робіт в області якості передбачає побудову структури i забезпечення іii ефективного функціонування, розподілу відповідальності, повноважень, взаємовідносин між працівниками, розробку відповідних схем зв'язків із зовнішніми організаціями, а також розробку системи якості. При цьому для створення системи якості, що відповідає сучасному рівню, використовуються рекомендації міжнародних стандартів ISO 9000:2009, в яких узагальнено досвід створення таких систем, накопичений у розвинених країнах.

Після розробки йде етап впровадження системи якості, протягом якого проводяться внутрішні перевірки системи i, як правило, iї доопрацювання за результатами перевірок. Завершальним етапом є сертифікація системи якості на відповідність стандартам ISO 9000. Одержання сертифікату від авторитетного незалежного органу істотно зміцнює позиції підприємства на ринках збуту, оскільки дає замовникам додаткову впевненість у можливості підприємства стабільно забезпечувати необхідний рівень якості. При організації робіт в області якості необхідно забезпечити на всіх етапах виробничого процесу застосування якісних матеріалів, сучасного устаткування, засобів вимірів, професійно підготовленого, мотивованого трудового потенціалу 3 творчим та інтелектуальним капіталом, необхідну документацію. 


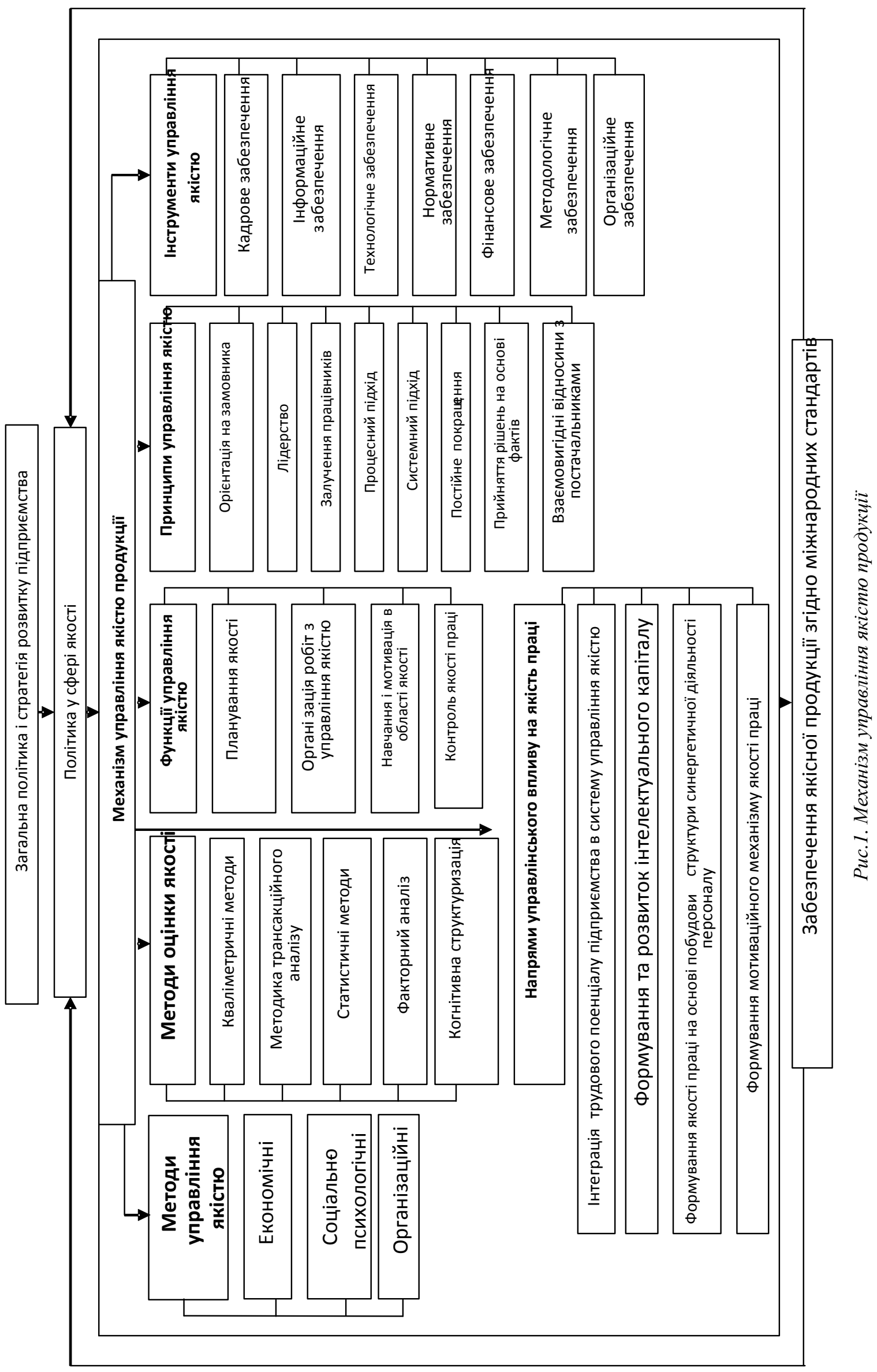

Вісник економіки транспорту і промисловості № 62, 2018 
Навчання і мотивація працівників спрямовані на формування активного i кваліфікованого трудового потенціалу, який поряд 3 матеріально-технічною базою i організацією робіт $є$ одним 3 основних факторів виготовлення високоякісної продукції [5]. Навчання працівників слід орієнтувати на виконання ключових функцій, серед яких: надання праці творчого характеру, згуртованість трудових колективів, формування i розвиток інтелектуального капіталу, підвищення кваліфікації працівників, зниження втрат від неефективних, нераціональних, некваліфікованих дій.

Працівники всіх рівнів управління повинні бути ознайомлені 3 основними положеннями чинного законодавства у сфері якості, в першу чергу - із законами про захист прав споживачів, сертифікацію, єдність вимірів, стандартизацію, міжнародними стандартами якості, методами, які використовуються для оцінки якості та iï підвищення, удосконалення технічного рівня знань, навчання в галузі технологічних інновацій у виробництві, раціональне використання природних ресурсів [6].

Так,

високотехнологічного

повинне чітко - розу забезпечення якості продукції, уміти правильно визначати політику у сфері якості i здійснювати стратегічне планування 3 урахуванням зовнішніх i внутрішніх факторів. Управлінський персонал повинен бути обізнаний 3 функціями своїх підрозділів у системі якості і методами їх виконання, досконало знати систему якості, усвідомлювати свою роль та місце в цій системі. Працівники служби якості повинні мати достатні теоретичні знання в сфері якості, мати досвід 3 розробки системи якості, практично здійснювати управління i контроль за якістю праці, знати технологію і організацію виробництва.

При навчанні виробничого персоналу необхідно усвідомлювати, що якість продукції формується у виробничому процесі, а методи розробки і виготовлення продукції повинні бути спрямовані на досягнення необхідних іiі технікоекономічних характеристик. Тому навчання якості нерозривно пов'язане з професійним навчанням, при якому рекомендується вивчати метрологію, статистику, кваліметрію, документи 3 стандартизації тощо.

Для навчання питанням якості необхідно залучати, крім сторонніх спеціалістів, власних працівників, які практично займаються питаннями якості та досконало знають специфіку підприємства. За результатами навчання повинна бути передбачена оцінка знань та умінь працівників для їх офіційної атестації, а також визначення можливостей їх професійного росту і просування по службі. При цьому необхідною умовою $є$ те, що працівники повинні чітко уявляти залежність кар'єрного зростання від результатів навчання. Для досягнення ефективності процесу формування якості праці необхідно запровадити процес постійного підвищення кваліфікації i перепідготовки працівників за всіма необхідними напрямками, у тому числі управлінням якістю продукції, вивченням нових властивостей продукції, методів забезпечення іiі якості та надійності. При цьому необхідно застосовувати диференційований підхід до навчання залежно від ролі і функцій працівників на підприємстві.

Під час планування потреб у загальній та професійній підготовці слід враховувати зміни, викликані характером процесів, що застосовуються на високотехнологічному підприємстві, етапами підвищення кваліфікації працівників та культурою підприємства. Це дає змогу забезпечити працівників знаннями та уміннями, які, разом із досвідом, підвищуватимуть їхню компетентність. Процес навчання повинен забезпечувати участь кожного працівника в управлінні якістю продукції. При цьому всі 
працівники підприємства повинні мати доступ до інформації про якість продукції; нововведення, які впроваджуються; поліпшення, які здійснюються на підприємстві тощо. Організацією навчання займається відділ або група підготовки кадрів, проте програми навчання з питань якості повинні розроблятись відділом якості із залученням, за необхідності, сторонніх спеціалістів.

Крім того, беручи активну участь у виробничому процесі, працівник повинен мати загальне уявлення про діючу систему якості продукції, усвідомлювати свою роль i місце в ній, взаємодіяти 3 іншими працівниками 3 приводу питань якості та адміністрацією. Комплекс цих та інших питань, що поповнюють професійні знання, повинен стати предметом спеціального навчання у сфері якості.

Мотивація працівників, як уже зазначалось, є однією з головних функцій управління якістю продукції високотехнологічного підприємства. Ефективність управління якістю продукції визначає система стимулів, які формують мотиви досягнення працівниками підприємства цілей в області якості. Від пов'язання цих стимулів з об'єктивно існуючими інтересами працівників, які постійно змінюються, залежать якісні результати їх праці і стан трудового колективу. Перелік заходів 3 мотивації працівників передбачає їх стимулювання шляхом підвищення заробітної плати та премії, надання можливостей реалізації власних цілей та інтересів, активізацію особистих та професійних якостей працівників, створення умов для продуктивної спільної роботи, можливості навчання та професійного росту, творчу реалізацію.

Контроль якості - одна 3 основних функцій у процесі управління якістю, складова частина управління якістю, яка зосереджена на виконанні вимог до якості. Значення контролю полягає в тому, що він дозволяє вчасно виявити причини недостатньої якості праці, оперативно усунути їх 3 мінімальними втратами. Ця діяльність включає проведення вимірів, експертизи, випробування, оцінювання однієї або декількох характеристик об'єкта і порівняння отриманих результатів із встановленими вимогами для визначення відповідності за кожною 3 цих характеристик.

Важливим елементом механізму управління якістю продукції $є$ принципи управління якістю, покладені в основу міжнародних стандартів ISO серії 9000:2009. Ці принципи є першоосновою систем управління якістю продукції.

Наступним елементом механізму управління якістю продукції $\epsilon$ методи, за допомогою яких здійснюється безпосередній вплив на якість продукції. До методів управління якістю продукції належать: соціальні, економічні та соціально-психологічні. Методи оцінки якості продукції включають евристичне прогнозування на основі експертної оцінки, трансакційний аналіз витрат на якість продукції, кваліметричний метод, економіко-математичне моделювання, статистичні методи, когнітивізацію.

Аналіз існуючих розробок 3 управління якістю продукції показує його недостатню соціальну орієнтованість, що призводить до негативних наслідків у загальному процесі управління якістю. Через те пропонується широке застосування соціальних методів управління якістю продукції, що створює об'єктивні передумови для накопичення інтелектуального капіталу, забезпечення якості праці на основі якості трудового потенціалу, формування працівників творчого типу. Методи активізації трудового потенціалу передбачають соціальне планування i прогнозування потреб працівників на основі експертної оцінки, методи стимулювання розвитку творчості, ініціативи, інноваційних здібностей, участь працівників у процесі управління якістю продукції. Виділення даних методів активізації трудового потенціалу обумовлене соціальною 
спрямованістю управління якістю продукції.

Інструментами моделі управління якістю продукції $є$ підтримка ефективного процесу забезпечення якості за рахунок: кадрового, інформаційного, технологічного, нормативного, фінансового, методологічного та організаційного забезпечення. На основі ефективної взаємодії елементів механізму управління якістю продукції можна сформулювати напрями управлінського впливу на якість продукції. Такими є: інтеграція трудового потенціалу в систему управління якістю продукції, розвиток інтелектуального капіталу, побудова структури синергетичної діяльності працівників, формування мотиваційного механізму якості праці. Використовуючи дані напрями, розробляється стратегія управління якістю продукції, яка відображається у політиці якості i зорієнтована на регулювання процесів в системі управління якістю, досягнення якості праці, розвитку трудового потенціалу i відповідає цілям розвитку підприємства. Метою стратегії управління якістю продукції $\epsilon$ забезпечення умов для формування якісних показників, розвитку трудового потенціалу, запобігання дефектів праці, накопичення інтелектуального капіталу.

Висновки: Таким чином, в умовах глобалізації ринків якість продукції і послуг виступає не лише складовою конкурентоспроможності виробника, вона $€$ необхідною передумовою функціонування підприємств та цілих країн. Головною орієнтацією, за таких умов, має стати спрямування до постійної адаптації та вдосконалення сучасних методів і моделей управління якістю продукції 3 тим, щоб якнайкраще забезпечити показники конкурентоспроможності високотехнологічного підприємства стосовно інших суб'єктів господарювання [7].

$$
\begin{array}{cr}
\multicolumn{2}{c}{\text { Запропонований }} \\
\text { управління }
\end{array}
$$

механізм продукції високотехнологічних підприємств дозволить науково обгрунтовано підійти до створення якісної продукції в умовах інформаційної економіки.

\section{ПЕРЕЛІК ВИКОРИСТАНИХ ДЖЕРЕЛ}

1. Соколовський С.А. Управління якістю виробництва та обслуговування: навчальний посібник / С.А.Соколовський, С.П. Павлов, М.В. Черкашина М.О. Науменко, Є.М.Грабовський. - Харків: НАНГУ, - 2015. - 264c.

2. Романовський О.Г. Аудит i оцінювання управлінської діяльності/ О.Г. Романовський, М. В. Черкашина, M.O. Науменко, Є.М.Грабовський, Т.В. Гура, С.В. Воробйова. - Х.: АВВМВСУ, 2014. $-296 \mathrm{c}$.

3. Боженко Л.І. Метрологія, стандартизація, сертифікація та акредитація/ Л.І. Боженко. - Львів: УАД, $2004-320 \mathrm{c}$.

4. Орлов П.А. Менеджмент качества и сертификация продукции: учебное пособие/ П.А. Орлов. - Х.: Издательский Дом «ИНЖЭК», 2004. - 304 c.

5. Каличева Н.Є. Удосконалення системи управління персоналом в умовах розвитку підприємства / Н.С. Каличева, M.I. Стецюк// Вісник економіки транспорту i промисловості: збірник науковопрактичних статей. - Харків: УкрДАЗТ, 2015. - Вип. 49. - С. 195 - 198.

6. Дикань В.Л. Забезпечення конкурентоспроможності підприємств : підручник / В.Л. Дикань, Ю.Т. Боровик, О.М. Полякова, Ю.М. Уткіна. - Х.: УкрДАЗТ, 2012. - 415 с.

7. Каличева Н.Є. Аналіз напрямів забезпечення конкурентоспроможності підприємств приладобудування в сучасних умовах /Н.С. Каличева, А.С. Сілантьєв// Вісник економіки транспорту i промисловості: збірник наукових праць. Харків, УкрДУЗТ, 2017 . - № 59 . -С. 122128. 